\title{
Significance of Good Governance for FDI Inflows in SAARC Countries
}

\author{
Mumtaz Hussain Shah ${ }^{1}$, Anum Gul Afridi ${ }^{2}$
}

\begin{abstract}
This paper studies the importance of good governance for FDI inflows in SAARC member countries for the time period of nine years, i.e. from 2006 to 2014. The worldwide governance indicators of Kaufmann, Kraay, and Zoido-Lobatón (1999) are used to investigate the impact of good governance on FDI inflows. Through random effects panel estimation technique, the results show that political stability and regulatory quality significantly and positively affect inward FDI. On the contrary, prevalence of corruption discourages multinationals to invest in SAARC countries. Moreover, conventional FDI location determinants like market size and development level continue to exert their positive influence. However, openness of the host economy and human capital, though equally important, are insignificant in terms of their possible sway on FDI inflows. The key finding is that good governance has significant impact on inward FDI in the SAARC region.

Keywords: Good governance, SAARC developing countries, FDI, panel data JEL Classification: C330, C550, F210, F550 and F680
\end{abstract}

\section{Introduction}

Developing countries generally fall short of generating enough resources for the economic progress and well-being of their people (Burdekin \& Langdana, 2015). Foreign Direct Investments (FDIs) can be one of the possible sources to fulfil this short fall (Shah \&Faiz, 2015). Academic research admits that FDIs can make considerable contribution to an economy's expansion by stimulating economic development (Soumaré and Tchana, 2015). In order to attract multinationals, developing countries formulate policy objectives for reforming the investing procedures to develop a superior and profitable business friendly setup which draws the attention of foreign investors (Almond, Ferner \& Tregaskis, 2015). In this scenario, the current study strives to investigate the significance of good governance practices in five host SAARC nations, namely, Bangladesh, India, Nepal, Pakistan and Sri Lanka, for overseas investors (Subasat \& Bellos, 2013).

World Development Report (2005) defined good governance as a business supporting environment that offers growth prospects and incentives for micro businesses

1 Assistant Professor, Institute of Management Studies, University of Peshawar

2 Post-graduate Scholar, Institute of Management Studies, University of Peshawar 
and multinational firms to make effective investments, generate employment and accelerate economic growth. It has been specified by Rodrik (2012) that good governance always concentrates on the improvement of organizations and institutions. Therefore, friendly business and investment governing policy mechanism improve the current state of various macro variables, for instance trade regulations, bribery, courts of law, legal framework, labour conventions, electricity, transportation, telecommunications, etc., the characteristics fundamentally sought by multinationals (White, Chizema, Canabal, \& Perry, 2015).

The flow of capital or assets from an investor's home country into a foreign country in the form of acquisition or merger with an organization is known as foreign direct investment. UNCTAD (2002) characterized FDI as a venture including an enduring relationship reflecting continual benefits and control by a foreign citizen into a business in an economy other than that of the citizen's. Similarly, World Bank (1992) characterised FDI as investment created in order to obtain an enduring management benefits (typically at least $10 \%$ of stock) in a venture working in a state outside the investor's country.

FDI is usually expected to be strongly associated with democratic governance, political stability, sound macroeconomic conditions and business friendly commercial environment of the host country (Bitzenis and Žugić, 2016). Investment enabling legal framework and property rights security also help in reducing overseas investors' scepticism regarding investments in the host nation (Shah, 2013a).

The term governance is described by the Asian Development Bank (1999) as the way in which power is practiced in the administration of a nation's social and budgetary assets for advancement. The idea of governance is allied with the management of development process in both public and private segments. Asian Development Bank (1999) described four essential components of good governance as accountability, participation, prediction and transparency.

United Nations Development Programme (UNDP) identifies governance from the perspective of human development. It characterises governance in a broader way as compared to the World Bank or Asian Development Bank. UNDP (1997) defined it as the involvement/participation of political, business and authoritative power in the management of national issues at various levels. It involves system, procedures, and societies, through which residents and groups clearly express their interests, practice their legitimate rights, meet their commitments and negotiate their differences. Governance is one of the key subjects regularly discussed in the International Monetary Fund (IMF, 2002). In its 1996 Partnership for Sustainable Global Growth declaration, IMF recognized good governance as a structure incorporating rule of law, enhancing 
productivity, ensuring accountability of public office holders in general, and handling bribery in particular (IMF, 1996). These are the fundamental components of a system in which both local and foreign businesses can flourish.

FDIs in South Asia were comparatively low due to the member countries' reluctance to embrace free trade and investment policies (Shah, 2011b). However, they have seen a surge since early 1990s as a result of measures adopted by the member states for engaging foreign investors (Shah, 2011e).

A bulk of FDIs is received by India, while countries like Maldives, Nepal, Afghanistan and Bhutan lag behind (Ekanayake \& Perera, 2015). In 1990 41.2\% of total SAARC FDIs flew into India. It grew up to $74.11 \%$ in 2004 and increased to $84.49 \%$ in 2013. Pakistan, in 1990, received 48.34\%, while Sri Lanka 7.47\%. However, by 2013 , both countries' share plunged to a mere $11.05 \%$ and $1.52 \%$, respectively (Gugler, 2015).

Total FDIs in SAARC were $\$ 2.03$ billion in 2000, which is 3.13\% of Asia and just $0.24 \%$ of the aggregate global foreign investment of $\$ 1,271$ billion. In 2013, SAARC's stake, in terms of FDI, in Asia and Worldwide was $7.92 \%$ and $2.89 \%$, respectively. Among developing countries, SAARC share of inward FDI in 1990 was $1.63 \%$ which increased to $7.86 \%$ in 2013 (UNCTAD, 2013).

The main focus of earlier researches was mostly on classical FDI determinants such as host market size, human capital, as well as macroeconomic indicators such as GNP, GDP, trade, balance of payments, employment level, inflation, government's fiscal and monetary policy etc. (Shah, 2012c). Inquiry into governance and its impact on FDI was mostly ignored by academics (Claessens \& Yurtoglu, 2013). The foremost reason for this was the non-availability of data on governance variables. However, the worldwide governance indicators, introduced by Kaufmann, Kraay, and Zoido-Lobatón (1999), enabled the academics to explore governance's impact on FDIs. The current study also uses Kaufmann et al.'s (1999) governance indicators along with conventional determinants of FDIs in order to empirically investigate the association between the variable of interest, i.e. governance, and FDIs in SAARC countries.

Though, sufficient literature is available on governance and FDIs, there is still a dearth of research exploring the same phenomenon in the SAARC region. This study attempts to fill this gap. This study will help future investors in their investment related decision making. It will also add to the current pool of knowledge regarding good governance and FDIs as well as the policies set by SAARC governments for overseas investors' facilitation. Moreover, the empirical results will provide practical insights into the positive and negative influences of governance variables on FDIs in South 
Asian countries. It will also help readers to acquire knowledge about governance and FDIs in general and provide them with empirical evidence apropos their association within SAARC countries. It can also set the foundations for further research on the same topic in several other geographic regions and different time periods with different control variables.

The findings of this study are applicable to South Asian Countries only for the time period of nine years, i.e. from 2006 to 2014 and shall not be generalised to the rest of the world unless the region or group of countries have similar socioeconomic and political standings.

Rest of the paper is organized as follows. Literature on governance and other FDI determinants are reviewed in Section 2 followed by the research hypotheses and theoretical framework. Methodology, variables explanation and model specification are given in Section 3. Estimation issues, analysis of data and interpretation of results are discussed in Section 4. Section 5 concludes the paper.

\section{Literature Review}

A number of determinants are identified in the empirical literature that affects inward FDIs. Among them, market size, development level, and human capital are the foremost ones. Globerman and Shapiro (2002) stated that a large market would seek more FDIs due to a number of reasons such as robust client base, possible economic clusters, or because of the expected economies of scale in bigger markets. According to Kristjánsdóttir and Óskarsdóttir (2012), for investors, market size and government efficiency have positive effect on foreign investment decision of multinationals. Development level also plays a vital role in attracting FDIs. Mottaleb (2007) stated that FDIs were attracted to the countries where GDP and GDP growth rate were high as well as where business friendly atmosphere and web facilities were easily accessible.

Wheeler and Mody (1992) and Shah (2011d) acknowledged that human capital presence is an essential pre-requisite for FDIs in High-Tec segments. Human capital is measured as either average year of schooling or primary, secondary or tertiary attainment levels. Moreover, Miyamoto (2008), Shah (2009), and Shah (2014b) show that for attracting FDI, at least primary education should be the minimum level of education required after mid-80s.

Yu and Walsh (2010) evaluated FDIs in a sample of 27 developed and developing countries for the period 1985-2008 in the primary, secondary, and tertiary sector. The findings revealed that macroeconomic factors such as inflation, work adaptability, legal framework effectiveness, education, exchange rate, trade, GDP etc. play a vital role for FDI inflows in manufacturing and service sectors. Balasubramanyam (2002) and Shah 
(2014a) considered infrastructure as another key FDI determinant. The negative association between FDI inflows and inflation, i.e. macroeconomic instability, is evident from Asiedu (2006) and Shah (2013b). Furthermore, Nunnenkamp (2002), analysing 28 developing nations from 1987 to 2000 found that FDIs are positively correlated with per capita GNP, factor costs, and years of education. According to Margalioth (2003) and Blonigen (2005), FDI inflows can be increased through tax incentives.

Mansfield (1995) demonstrated that intellectual property rights (IPRs) are important for entrepreneurs of pharmaceutical sector. Maskus (2000) said that FDIs can be enhanced through strong IPR promulgation with the help of a supportive legal and regulatory framework. Smarzynska (2002) and Shah (2012a) considered it as one of the most important factors for attracting investments and found a significant positive effect of IPRs on FDIs. Biglaiser and Staats (2010), reviewing U.S joint ventures in Latin America, attested that by strengthening their property rights, rule of law, and legal courts, these countries witnessed increase in inward FDIs. Hewko (2003) asserted that an investor from a country with a corrupt government is indifferent towards the host country's weak legal system in comparison to the investor from a legally resilient state. On the contrary, Peters (2002) found overseas investors to be neutral to the quality of the host country's legal system.

Busse (2003), Jensen (2003), Li and Resnick (2003), and Pierpont (2007) conducted research on FDIs and democratic governance and concluded that countries where democracy prevails draw more foreign investments. Furthermore, Porta, Lopez-De-Silanes, Shleifer and Vishny (1997) and Shah (2010) claimed that countries which fail to ensure investor security witness a loss of FDIs.

Meon and Sekkat (2007) examined FDIs and governance relationship by utilizing Kaufmann et al.'s (1999) governance indicators in 96 countries. It was found that FDIs and institutional governance are positively related. Globerman and Shapiro (2002) also used the same governance indicators for 144 countries from 1994-1997 to analyse the influence of good governance on U.S FDIs. Their results showed that U.S investors consider the existence of sound governance setup as one of the most important requisites of FDIs. Governance-FDI nexus in Ethiopia was explored by Daddi (2013) through interviewing 150 experts selected from 12 institutions. It was found empirically that the three parameters for governance, i.e. efficiency, accountability, and decency of public office holders have a significant positive effect on FDIs.

Busse and Hefeker (2007) analysed political risk, institutions, and FDI relationship for 83 developing countries from 1984-2003. It was found that government stability, reduced corruption and domestic conflicts, sound law and order situation, democracy, accountability and lower bureaucratic mingling positively influenced FDIs. Wei and 
Shleifer (2000) and Habib and Zurawicki (2002) found that political stability has positive influence on FDIs. Shah and Faiz (2015) found that countries plagued with terrorism and a high political risk deter FDIs.

Seim (2010) found in his study that improved regulatory quality positively influences inward FDIs. Bissoon (2011) analysed the impact of institutional quality on FDIs by using data for 45 developing countries from Africa, Asia and Latin American. The results showed that stable and strong regulatory laws, low corruption in institutions, and political stability enhance inward FDIs in these countries. Daude and Stein (2007) using 34 source countries and 152 host economies found that regulatory quality and government effectiveness play a vital role in affecting FDIs. Other variables such as corruption, rule of law, political stability and voice and accountability had no significant impact on FDIs. Bénassy-Qu'éré, Coupet, and Mayer (2007) investigating institutional determinants of FDIs from 1985-2000 concluded that low corruption, efficient bureaucracy, vibrant courts, access to information, and a developed banking sector are essential factors for FDI inflows. According to Brada, Drabek, and Perez (2012), excessive corruption could ruin the volume of incoming FDIs. Voyer and Beamish (2004), studying how the level of corruption affects Japanese FDIs in 59 developed and developing countries, found that corruption and FDIs were negatively related. Similarly, Shah (2011b) shows that corruption, absence of government effectiveness, and rule of law have negative influence, while political stability and regulatory quality have a positive significant impact on inward FDIs. Therefore, we postulate that good governance shall exert a significant positive effect on inward FDIs in SAARC countries.

On the basis of above literatures following hypotheses are developed to achieve the research objectives of the study.

$\mathrm{H}_{0}$ : Governance indicators have no impact on inward FDIs in SAARC countries.

$\mathrm{H}_{1}$ : Governance indicators have significant impact on inward FDIs in SAARC countries.

The theoretical framework outlining the relationship between the dependent and all the independent variables is given as Figure 1. 


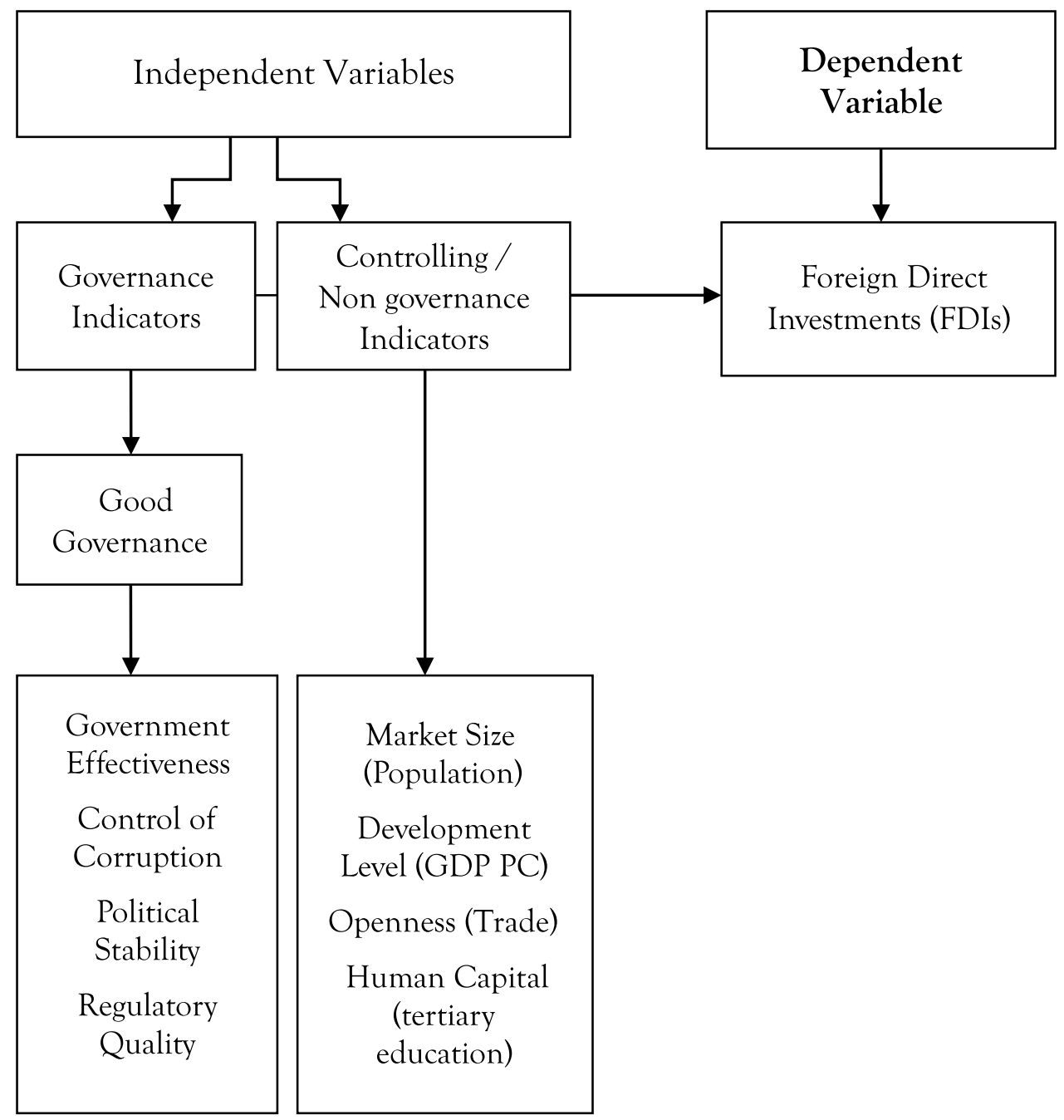

Figure 1: Schematic Representation of the Model

\section{Methodology}

In this section, methodology of the paper is presented. This includes variables' explanation, sampling design, data collection, and model specification.

\subsection{Variables' Explanation}

\subsubsection{Dependent variable: Foreign Direct Investments}

When multinationals enter a foreign market either by acquiring a firm or broadening the existing business activities in the host country, it is called foreign direct 
investment (FDI). The data for annual net FDI inflows is taken from World Bank, World Development Indicators (WB, WDI) for five SAARC countries to gauge the influence of good governance on inward FDIs.

\subsubsection{Independent / Controlling Variables}

Eight independent variables are considered for this study. The four non-governance control variables are market size, development level, openness, and human capital; while the governance indicators include political stability, regulatory quality, control of corruption, and government effectiveness. Nineteen proxies were initially selected for independent variables. However, based on their association and significance, only eight proxies were incorporated in the model which is explained below in detail. The omitted proxies are GDP (gross domestic product), primary education, secondary education, average years of schooling, life expectancy, voice and accountability, rule of law, government size, government enterprise investment, legal system, property rights, and inflation.

\subsubsection{Market Size}

Among all the determinants of FDIs, market size is considered as the most crucial factor for attracting MNCs (Wheeler \& Mody, 1992; Kok \& Ersoy, 2009). Market size has a positive significant relationship with FDI inflows. Aggregate population is taken from WB, WDI as a proxy for market size for each SAARC member. Market seeking FDIs target large markets for introducing their products due to high expected demand and possible economies of scale and availability of skilled labour (Shah, 2011f).

\subsubsection{Development Level}

Development level, proxied by GDPPC in current US dollars, signifies peoples' living standard as well as the extent of economic progress of a country. It is the second most important determinant of FDIs (Shah, 2012b). The data is collected from WB, WDI. GDPPC seems more useful while making comparison of one country with another. Higher GDPPC means higher living standard of a country's citizens and a sign of substantial economic growth. Foreign investors prefer those countries where average income and standard of living is high because people have superior buying power. According to Schneider and Frey (1985) and Shah (2011a), there is a significant positive association between FDIs and per capita GDP.

\subsubsection{Openness}

The degree to which a country is linked with outside world and allows the import of raw material and export of finished products is important for multinationals 
(Shah, 2015). Trade as a percentage of GDP is used as a proxy for openness of the host nation. It is taken from WB, WDI. Previous studies like Edwards (1992), Gastanaga, Nugent and Pashamova (1998), Goldar and Banga (2007), and Shah and Samdani (2015) have shown positive effect of trade liberalisation on FDIs. Trade openness in vertical FDIs positively affects FDIs as trade barriers and tariffs are not there to hinder MNCs' activities. However, in market seeking horizontal FDIs, a negative or altogether insignificant association is expected.

\subsubsection{Human Capital}

Like other factors, human capital is also an essential determinant of FDIs. It is measured through level of education, capabilities, and aptitude of labour force. Both health and education are important for the capacity building of a country's skilled, qualified and efficient pool of labour. Researches by Schneider and Frey (1985), Loree and Guisinger (1995), Khan (2007) and Shah (2011c) have stated that a positive relation exists between human capital and inward FDIs. Generally, countries with abundant cheap and skilled human capital draw more FDIs, especially in labour intensive industries. Tertiary education from Barro and Lee's (2013) education data set is used as a proxy for human capital in the current study.

\subsection{Independent Variable - Good Governance}

The key independent variable of this study is good governance. World Bank, Worldwide Governance Indicators (WB, WGI, 2015) project reports aggregate and individual governance indicators for 215 economies over the period 1996-2014 for six dimensions of governance which are: voice and accountability, political stability and absence of violence, government effectiveness, regulatory quality, rule of law, control of corruption.

WGIs were developed by Kaufmann et al. (1999) and are therefore known as Kaufmann et al. governance indicators. Good governance is defined by WGI (2015) as the culture and manner by which power is practiced in a nation. It incorporates the method by which governments are chosen, screened, and reinstated. It is the ability of the authorities to successfully develop and enforce sound strategies, and the appreciation by people and state for the organizations that administer monetary and social connections around them. Political stability, regulatory quality, control of corruption, and government effectiveness are selected as proxies for good governance from WBWGI (2015) in order to assess the impact of good governance over inward FDIs in SAARC nations. The value of all governance indicators varies from -2.5 to +2.5. As evident from the literature review, existing researches show that good governance positively affects inward FDIs. Therefore, we also expect a positive association 
between the two.

\subsubsection{Political Stability}

Political stability is interpreted as the extent to which government is stable. It identifies the chances of premature dissolution of the government in office due to political turmoil. Multinationals prefer democratic states with steady and stable business friendly policies, expecting them to be supportive of international investments and businesses. Moreover, MNCs anticipate a lesser risk of expropriation from such states. Therefore, we expect a positive effect of political stability on inward FDIs.

\subsubsection{Regulatory Quality}

Regulatory quality is the ability of the government through which reliable and consistent regulatory policies are created and implemented. These government regulations help boost both government and private sector development and also give an indication of the degree of market friendliness for overseas investors. If the regulatory quality is high, a positive influence on overseas investments is expected as multinationals seek locations where the regime is market friendly.

\subsubsection{Control of Corruption}

Control of corruption shows the extent of corruption prevalence in bureaucracy and their ability to get kickbacks through exploitation of their position. As evident from the literature review, multinationals abhor pervasiveness of corruption and bureaucratic red-tapism. Therefore, we expect that corruption control shall positively affect multinationals' investment decisions.

\subsubsection{Government Effectiveness}

A government is said to be effective if the civilians are provided with best quality services and their lives are free from political pressures. Effective governments can better facilitate multinationals' operations. Constant government policies are preferred by overseas investors because it helps them make appropriate budgetary allocations sans frequent and unexpected repetitions. A stable government guarantees the continuation of policies; therefore, a positive relationship between FDIs and government effectiveness is expected.

The sources, proxies and abbreviations used for all the above mentioned variables are summarised in Table 1. 
Table 1: Variables, their proxies and sources

\begin{tabular}{|c|c|c|c|}
\hline Variables & Proxy & Abbreviation & Sources \\
\hline $\begin{array}{c}\text { Foreign Direct Invest- } \\
\text { ment }\end{array}$ & LNFDI & Ln FDI & WB, WDI \\
\hline Market Size & Ln population & Ln Pop & WB, WDI \\
\hline Development Level & Ln GDPPC & Ln GDPPC & WB, WDI \\
\hline Openness & $\begin{array}{l}\text { Ln trade as a \% of } \\
\text { GDP }\end{array}$ & Ln Trade & WB, WDI \\
\hline Human Capital & Ln tertiary education & Ln TrEdu & $\begin{array}{c}\text { Barro \& Lee Educa- } \\
\quad \text { tion Dataset }\end{array}$ \\
\hline Good Governance* & $\begin{array}{c}\text { Political Stability Regu- } \\
\text { latory Quality Control } \\
\text { of Corruption Govern- } \\
\text { ment Effectiveness }\end{array}$ & $\begin{array}{c}\text { PolStab RegQu CoCr } \\
\text { GovEf }\end{array}$ & $\begin{array}{l}\text { World Bank, World- } \\
\text { wide Governance } \\
\text { Indicators }\end{array}$ \\
\hline
\end{tabular}

* The governance variables are taken without $\log$ because their values vary between -2.5 to +2.5 .

\subsection{Sample}

The paper studies the importance of good governance for inward foreign direct investments in five SAARC members: Bangladesh, India, Nepal, Pakistan and Sri Lanka, for a period of nine years, i.e. from 2006 to 2014. Afghanistan, Bhutan and Maldives, though SAARC members, were excluded due to non-availability of data for all the variables.

\subsection{Data Collection}

The data used is secondary in nature and is collected from World Bank, World Development Indicators (WB, WDI) and Barro and Lee's (2013) educational data set. These sources are also given in Table 1 .

\subsection{Model Specification}

The influence of good governance over incoming FDIs can be estimated through the following equation:

$F D I_{j t}=f($ Market Size,Development Level, Openness, Human Capital, Good Governance) $)_{j t}$

Where

FDI is the dependent variable, Controlling factors are market size, development level, openness and human capital, Good governance is the major explanatory or 
independent variable, " $\mathrm{j}$ " varies from 1 to 5 representing the member countries, " $\mathrm{t}$ " is for the time period 2006-2014 varying from 1 to 9 .

Substituting relevant proxies for the explanatory variables in equation 1 and $\log$ linearizing it, we get:

$$
\begin{aligned}
& \operatorname{LnFDI}_{j t}=\alpha_{0}+\beta_{1} \operatorname{LnPop}_{j \mathrm{t}}+\beta_{2} \operatorname{LnGDPPC}_{j \mathrm{t}}+\beta_{3} \text { LnTrade }_{j \mathrm{t}}+\beta_{4} \operatorname{TrEdu}_{j \mathrm{t}}+\beta_{5} \text { PolStab }_{j \mathrm{t}} \text { or } \\
& \beta_{5} \operatorname{Reg} \mathrm{Q}_{\mathrm{jt}} \text { or } \beta_{5} \mathrm{CoCr}_{j \mathrm{t}} \text { or } \beta_{5} \mathrm{GovEf}_{j \mathrm{t}}+\varepsilon_{\mathrm{jt}}
\end{aligned}
$$

Where $\mathrm{Ln}$ is used for natural logarithm, LnFDI is the dependent variable. Proxies for independent / controlling variables' proxies are:

LnPop $=$ Market Size

LnGDPPC $=$ Development Level

LnTrade $=$ Openness

LnTrEdu = Human Capital

Good Governance proxies that are incorporated in the model are:

PolStab $=$ Political Stability

RegQu = Regulatory Quality

$\mathrm{CoCr}=$ Control of Corruption

GovEf $=$ Government Effectiveness

$\alpha_{0}$ is the intercept and $\varepsilon_{j t}$ is the error term.

\section{Results and Analysis}

Secondary data for five SAARC countries are collected for nine years over the time period of 2006 to 2014. Descriptive statistics for all variables are presented in Table 2. They include total observations available for all the variables along with minimum, maximum, mean, median, and variance values for each of them.

Heteroscedasticity, uncovered by Breusch-Pagan/Cook-Weisberg test, was removed by using the option of robust standard errors. Table 3 shows correlations among all variables of the study. There was no multi-collinearity found among explanatory variables as the VIF values for all variables were found to be less than 10 .

To choose an appropriate estimation technique between possible regression 
Table 2: Descriptive statistics*

\begin{tabular}{|c|c|c|c|c|c|c|c|}
\hline Variables & Proxies & Obs & Min & Max & Mean & Median & Variance \\
\hline $\begin{array}{l}\text { Foreign } \\
\text { Direct In- } \\
\text { vestment }\end{array}$ & Ln FDI & 45 & -15.7098 & 24.4938 & 17.0684 & 19.9886 & 103.6926 \\
\hline $\begin{array}{c}\text { Market } \\
\text { Size }\end{array}$ & Ln Pop & 45 & 16.7492 & 20.8979 & 18.4654 & 18.7473 & 2.1624 \\
\hline $\begin{array}{c}\text { Devel- } \\
\text { opment } \\
\text { Level }\end{array}$ & $\begin{array}{c}\text { Ln GDP- } \\
\text { PC }\end{array}$ & 45 & 5.4212 & 7.6083 & 6.3411 & 6.2396 & 0.2915 \\
\hline Openness & Ln Trade & 45 & 3.2819 & 4.4957 & 3.8020 & 3.8115 & 0.1043 \\
\hline $\begin{array}{l}\text { Human } \\
\text { Capital }\end{array}$ & Ln TrEdu & 45 & 0.9001 & 2.2877 & 1.4728 & 1.3687 & 0.2036 \\
\hline \multirow{4}{*}{$\begin{array}{l}\text { Good } \\
\text { Gover- } \\
\text { nance }\end{array}$} & PolStab & 45 & -2.5826 & -0.7668 & -1.4842 & -1.4529 & 0.1848 \\
\hline & RegQu & 45 & -1.0952 & 0.2477 & -0.5014 & -0.5006 & 0.1147 \\
\hline & $\mathrm{CoCr}$ & 45 & -1.4888 & -0.1018 & -0.6533 & -0.6268 & 0.1427 \\
\hline & GovEf & 45 & -0.8649 & 0.3250 & -0.4202 & -0.4521 & 0.0727 \\
\hline
\end{tabular}

*Values rounded off to four decimal places

Table 3: Correlation matrix*

\begin{tabular}{|c|c|c|c|c|c|c|c|c|c|c|c|}
\hline No & $\begin{array}{c}\text { Variable } \\
\text { Name }\end{array}$ & $\begin{array}{c}\text { Proxy } \\
\text { used }\end{array}$ & 1 & 2 & 3 & 4 & 5 & 6 & 7 & 8 & 9 \\
\hline 1 & $\begin{array}{c}\text { Foreign } \\
\text { Direct Invest- } \\
\text { ment }\end{array}$ & Ln FDI & 1.00 & & & & & & & & \\
\hline 2 & Market Size & Ln Pop & 0.45 & 1.00 & & & & & & & \\
\hline 3 & $\begin{array}{l}\text { Develop- } \\
\text { ment Level }\end{array}$ & $\begin{array}{l}\mathrm{Ln} \\
\text { GDP- } \\
\text { PC }\end{array}$ & 0.53 & 0.02 & 1.00 & & & & & & \\
\hline 4 & Openness & $\begin{array}{c}\text { Ln } \\
\text { Trade }\end{array}$ & -0.14 & -0.67 & 0.45 & 1.00 & & & & & \\
\hline 5 & $\begin{array}{l}\text { Human } \\
\text { Capital }\end{array}$ & $\begin{array}{c}\text { Ln } \\
\text { TrEdu }\end{array}$ & 0.40 & -0.23 & 0.86 & 0.49 & 1.00 & & & & \\
\hline 6 & Good Gover- & PolStab & 0.25 & 0.28 & 0.09 & 0.03 & 0.12 & 1.00 & & & \\
\hline 7 & nance & RegQu & 0.07 & -0.17 & 0.51 & 0.60 & 0.56 & 0.12 & 1.00 & & \\
\hline 8 & & $\mathrm{CoCr}$ & -0.05 & -0.18 & 0.44 & 0.54 & 0.47 & 0.13 & 0.87 & 1.00 & \\
\hline 9 & & GovEf & 0.36 & 0.35 & 0.63 & 0.20 & 0.54 & 0.42 & 0.69 & 0.73 & 1.00 \\
\hline
\end{tabular}

*Values rounded off to two decimal places 
methods, first the F-Test was performed to make a choice between the pooled OLS and fixed effects panel method. The null hypothesis that the pooled OLS model is adequate, can easily be rejected in favour of the fixed effects alternative with the following statistical values $F(4,32)=11.6325$ and a probability value of 0.0000 . Next, a Breusch-Pagan Langrage Multiplier test was performed to know whether pooled OLS or random effect panel model shall be used. The probability statistic values of 0.0000 once more conveniently reject the null hypothesis that the pooled OLS model is adequate, in favour of the random effects alternative.

Finally, Hausman (1978) specification test was performed to choose the appropriate panel estimation method between the fixed and random effects. The probability value of Hausman test was 0.8560 which showed that we cannot reject the null hypothesis that the results obtained with consistent fixed effects and efficient random effects are identical (Shah, 2012d). The three tests are summarised in Table 4. This permits us to use random effect panel estimation technique. All the empirical estimation and tests are performed by Stata 11 .

Table 4: Specification tests

\begin{tabular}{|c|c|c|c|c|}
\hline Test & Choose Between & Null Hypothesis & P-Value & Result \\
\hline F-Test & $\begin{array}{c}\text { Panel Fixed } \\
\text { Effects \& Pooled } \\
\text { OLS }\end{array}$ & $\begin{array}{c}\text { Pooled OLS is } \\
\text { better }\end{array}$ & 0.0000 & Use Fixed Effects \\
\hline $\begin{array}{c}\text { Langrage Multi- } \\
\text { plier Test }\end{array}$ & $\begin{array}{c}\text { Panel Random } \\
\text { Effects \& Pooled } \\
\text { OLS }\end{array}$ & $\begin{array}{c}\text { Pooled OLS is } \\
\text { better }\end{array}$ & 0.0000 & $\begin{array}{c}\text { Use Random } \\
\text { Effects }\end{array}$ \\
\hline Hausman Test & $\begin{array}{c}\text { Random Effects } \\
\text { \& Fixed Effects }\end{array}$ & $\begin{array}{c}\text { Fixed \& Random } \\
\text { Effects Give the } \\
\text { same results }\end{array}$ & 0.8560 & $\begin{array}{c}\text { Can use Random } \\
\text { Effects }\end{array}$ \\
\hline
\end{tabular}

Table 5 shows regression results of the study based on random effects technique. Column 1 shows that market size is insignificant. However, in the second model (Column 2) when GDPPC proxying development level and purchasing power is added, it turns positive. It shows that multinationals seek bigger markets but the people should also have the ability to buy their end products.

Trade openness and human capital both are insignificant in all the regressions/ models. The reason for human capital being insignificant can be that GDPPC not only exhibits development level and purchasing power of the people but also their extent of education. Hence GDPPC being significant may be overwhelming the possible significance of tertiary education used as a proxy for human capital. Though 
not reported in Table 5, but if the variables are regressed without the GDPPC proxy for development level, the coefficient for human capital becomes highly significant at five percent level.

For the insignificance of openness, the only plausible explanation is that the nature of FDIs in SAARC region is of market seeking horizontal nature. In horizontal FDIs, trade openness can negatively affect multinational sales in the host market. This may also partly justify the insignificance of human capital because in horizontal FDIs multinationals concentrate on low skilled mass production or essentially, the economies of scale.

Table 5: Regression analysis by random effects panel estimation method

\begin{tabular}{|c|c|c|c|c|c|c|c|}
\hline Variable & $\begin{array}{l}\text { Proxy } \\
\text { Used }\end{array}$ & 1 & 2 & 3 & 4 & 5 & 6 \\
\hline $\begin{array}{l}\text { Market } \\
\text { Size }\end{array}$ & Ln Pop & $\begin{array}{l}3.4156 \\
(2.3372)\end{array}$ & $\begin{array}{l}3.0216^{* * *} \\
(1.0854)\end{array}$ & $\begin{array}{l}2.1198^{* * *} \\
(0.7526)\end{array}$ & $\begin{array}{l}2.4318^{* *} \\
(1.1695)\end{array}$ & $\begin{array}{l}1.8662^{*} \\
(1.0259)\end{array}$ & $\begin{array}{c}2.3536^{* * *} \\
(0.7866)\end{array}$ \\
\hline $\begin{array}{l}\text { Devel- } \\
\text { opment } \\
\text { Level }\end{array}$ & $\begin{array}{c}\text { Ln GDP- } \\
\text { PC }\end{array}$ & & $\begin{array}{l}7.8817^{* * *} \\
(3.2807)\end{array}$ & $\begin{array}{l}8.8748^{*} \\
(4.8488)\end{array}$ & $\begin{array}{c}8.1575 \\
(5.5544)\end{array}$ & $\begin{array}{c}10.2120^{* * *} \\
(4.2273)\end{array}$ & $\begin{array}{c}10.9082^{* * *} \\
(3.8186)\end{array}$ \\
\hline Openness & Ln Trade & & & $\begin{array}{c}-6.1412 \\
(7.7931) \\
\end{array}$ & $\begin{array}{c}-6.1977 \\
(6.4060) \\
\end{array}$ & $\begin{array}{l}-5.5996 \\
(6.5629) \\
\end{array}$ & $\begin{array}{l}-5.8690 \\
(5.8247) \\
\end{array}$ \\
\hline $\begin{array}{l}\text { Human } \\
\text { Capital }\end{array}$ & Ln TrEdu & & & & $\begin{array}{l}4.6226 \\
(5.0004)\end{array}$ & $\begin{array}{c}3.3678 \\
(3.2439)\end{array}$ & $\begin{array}{l}3.8902 \\
(2.7551)\end{array}$ \\
\hline \multirow{4}{*}{$\begin{array}{l}\text { Good } \\
\text { Gover- } \\
\text { nance }\end{array}$} & PolStab & & & & & $\begin{array}{c}3.2944^{* * *} \\
(1.3003)\end{array}$ & $\begin{array}{c}4.0635^{* * *} \\
(1.6899)\end{array}$ \\
\hline & RegQu & & & & & $\begin{array}{c}5.3185^{*} \\
(2.9685)\end{array}$ & $\begin{array}{l}5.7357^{*} \\
(2.9762)\end{array}$ \\
\hline & $\mathrm{CoCr}$ & & & & & $\begin{array}{c}-10.4107^{* * *} \\
(2.7499)\end{array}$ & $\begin{array}{l}-7.7467^{* *} \\
(3.8823)\end{array}$ \\
\hline & GovEf & & & & & & $\begin{array}{l}-6.5049 \\
(4.6723)\end{array}$ \\
\hline \multicolumn{2}{|c|}{$\begin{array}{c}\text { Number of Observa- } \\
\text { tions }\end{array}$} & 45 & 45 & 45 & 45 & 45 & 45 \\
\hline $\mathrm{R}$ square & & $20.00 \%$ & $46.29 \%$ & $47.50 \%$ & $49.41 \%$ & $55.45 \%$ & $55.77 \%$ \\
\hline
\end{tabular}

Coefficient values rounded off to four decimal places. Robust standard errors are given in parenthesis below the coefficients. ${ }^{* * *},{ }^{* *},{ }^{*}$ show Significance at $1 \%, 5 \%$, and $10 \%$, respectively 
Political stability and regulatory quality (Column 5) both are positively significant, signifying the importance of these two phenomena for the overseas investments. Also, evident form the same model is the strong negatively significant coefficient of prevalence of corruption in the polity and public offices. This clearly manifests that multinationals seek locations where the bureaucracy is efficient, devoid of any red-tape culture, and free of corruption. Though government effectiveness is insignificant in Column 6, yet it can be seen that the coefficient for corruption falls from - 10.4107 to -7.7467, clearly indicating that as the government becomes effective the possibility of bribery and coercion or swindling the local as well as the foreign investor decreases. Moreover, the significance of political stability and regulatory quality remains the same with much stronger coefficients with the inclusion of government effectiveness in Column 6.

The positive significance of political stability and regulatory quality along with the negatively significant coefficient for corruption clearly manifests foreign investors' abhorrence for corruption and their desire for good governance.

\section{Conclusion}

This research is undertaken with the purpose of analysing the impact of good governance on inward FDIs in five SAARC countries over the period of 2006-2014. The sample comprised of five of the total 8 SAARC countries, namely, Bangladesh, India, Nepal, Pakistan and Sri Lanka. The three other SAARC countries, Afghanistan, Bhutan and Maldives were excluded because of the deficiency of complete dataset on important variables. The empirical results showed that market size (population) and development level (GDPPC) are statistically significant and positively affect FDIs, whereas openness, i.e. trade, and human capital, i.e. tertiary education have no significant influence on inward FDIs which means that they are not playing any part in enhancing inward FDI in the SAARC region.

Political stability was statistically positively significant which is in conformity with our earlier expectations, and therefore proves that the better a recipient country's environment is in terms of political stability; higher will be the likelihood of foreign investment in that country. Similarly, regulatory quality exhibited a significant positive influence on inward FDIs, i.e. the stronger the rules and regulatory policies of a country are concerning market facilitation of overseas investors, the better will be the response of multinationals in the form of investments. Corruption displayed a negatively significant relationship with inward FDIs. This highlights the fact that pervasiveness of corruption is loathed by multinationals and they avoid such places where they incur additional costs in the form of corruption. 
To sum up the results, good governance is one of the crucial factors which multinationals consider when choosing a foreign site as a possible FDI destination especially in the SAARC countries. Therefore, the policy makers should ensure to include them in the broader mechanism developed to attract overseas investors in SAARC economies in particular and other developing countries in general.

\section{References}

Almond, P., Ferner, A., \& Tregaskis, O. (2015). The changing context of regional governance of FDI in England. European Urban and Regional Studies, 22(1), 61-76.

Asian Development Bank. (1999). Annual Report 1998. Manila.

Asiedu, E. (2006). Foreign direct investment in Africa: The role of natural resources, market size, government policy, institutions and political instability. The World Economy, 29(1), 63-77.

Balasubramanyam, V.N. (2002). Foreign direct investment in developing countries: Determinants and impact. In New Horizons for Foreign Direct Investment. Paris: Organization for Economic Co-operation and Development (OECD).

Barro, R.J., \& Lee, J.W. (2013). A new data set of educational attainment in the world, 1950-2010. Journal of Development Economics, 104, 184-198.

Bénassy-Qu'éré, A., Coupet, M. \& Mayer, T. (2007). Institutional determinants of foreign direct investment. The World Economy, 30(5), 764-782.

Biglaiser, G. \& Staats, J. (2010). Do political institutions affect foreign direct investment? A survey of US corporations in Latin America. Political Research Quarterly, 63(3), 508-522.

Bissoon, O. (2011). Can better institutions attract more foreign direct investment (FDI)? Evidence from developing countries. In International Conference on Applied Economics (59-70).

Bitzenis, A.P., \& Žugić, V.P. (2016). Barriers for FDI in Serbia: Evidence from the manufacturing sector. Global Business and Economics Review, 18(2), 227-246.

Blonigen, B.A. (2005). A review of the empirical literature on FDI determinants. Atlantic Economic Journal, 33(4), 383-403.

Brada, J.C., Drabek, Z., \& Perez, M.F. (2012). The effect of home-country and host-country corruption on foreign direct investment. Review of Development Economics, 16(4), 640-663.

Burdekin, R., \& Langdana, F. (2015). Budget deficits and economic performance (routledge revivals). Routledge.

Busse, M. (2003). Democracy and FDI (No. 220). Hamburg Institute of International Economics (HWWA).

Busse, M., \& Hefeker, C. (2007). Political risk, institutions and foreign direct investment. European Journal of Political Economy, 23(2), 397-415. 
Claessens, S., \& Yurtoglu, B.B. (2013). Corporate governance in emerging markets: A survey. Emerging Markets Review, 15, 1-33.

Daddi, T. (2013). The impact of governance on foreign direct investment performance in Amhara region. Available at SSRN 2209773.

Daude, C. \& Stein, E. (2007). The quality of institutions and foreign direct investment. Economics and Politics, 19(3), 317-344.

Edwards, S. (1992). Capital flows, foreign direct investment, and debt-equity swaps in developing countries (No. 3497). National Bureau of Economic Research, Inc.

Ekanayake, R., \& Perera, N. (2015). Stimulating intra-regional investment in SAARC. Is a regional investment agreement the way forward? South Asia Economic Journal, 16(2), 75-101.

Gastanaga, V., Nugent, J. \& Pashamova, B. (1998). Host country reforms and FDI inflows: How much difference do they make? World Development, 26(7), 1299-1314.

Globerman, S. \& Shapiro, D. (2002). Governance infrastructure and US foreign direct investment. Journal of International Business Studies, 34(1), 19-39.

Goldar, B., \& Banga, R. (2007). Impact of Trade Liberalization on Foreign Direct Investment in Indian Industries (No. 36). United Nations Economic and Social Commission for Asia and the Pacific (ESCAP).

Gugler, P. (2015). World Investment Report 2014: Investing in the SDGs: An Action Plan.

Habib, M. \& Zurawicki, L. (2002). Corruption and foreign direct investment. Journal of International Business Studies, 33(2) 291-307.

Hausman, J.A. (1978). Specification tests in econometrics. Econometrica, 46(6), 1251-1271.

Hewko, J. (2003). Foreign direct investment in transitional economies: Does the rule of law matter. East European Constitutional Review, 11, 71-79.

IMF (1996). Partnership for Sustainable Global Growth. Washington, DC: International Monetary Fund.

IMF (2002). Good Governance: The IMF's Role. Washington, DC: International Monetary Fund

Indicators, W.G. (2015). The World Bank Group. The World Bank Group.

Jensen, N. (2003). Democratic governance and multinational corporations: Political regimes and inflows of foreign direct investments. International Organization, 57(3), 587-616.

Kaufmann, D., Kraay, A., \& Zoido-Lobatón, P. (1999). Aggregating governance indicators. World Bank Research Working Papers, No. 2196.

Khan, M. (2007). Role of human capital in attracting foreign direct investment: A South Asian perspective. SAARC Journal of Human Resource Development, 3(1), 5-25.

Kok, R. \& Ersoy, A.B. (2009). Analysis of FDI determinants in developing countries. International Journal 
of Social Economics, 36(1/2), 105-123.

Kristjánsdóttir, H., \& Óskarsdóttir, S. (2012). What determines the inflow of foreign direct investment? Rannsóknir i félagsvísindum XIII. Erindi flutt à rádstefnu i október 2012. Reykjavík: The Social Science Research Institute, University of Iceland.

Li, Q. \& Resnick, A. (2003). Reversal of fortunes: Democratic institutions and foreign direct investment inflows to developing countries. International Organization, 57(1), 175-212.

Loree, D. \& Guisinger, S. (1995). Policy and non-policy determinants of US equity foreign direct investment. Journal of International Business Studies, 26(2), 281-300.

Mansfield, E. (Ed.). (1995). Intellectual property protection, direct investment, and technology transfer: Germany, Japan, and the United States (Vol. 27). World Bank Publications.

Margalioth, Y. (2003). Tax competition, foreign direct investments and growth: Using the tax system to promote developing countries. Virginia Tax Review, 23(1), 161-208.

Maskus, K.E. (2000). Intellectual Property Rights and Foreign Direct Investment. Centre for International Economic Studies, Policy Discussion Paper No. 0022.

Meon, P. \& Sekkat, K. (2007). Revisiting the relationship between governance and foreign direct investment. Brussels Economic Review, 50(1), 41-61.

Miyamoto, K. (2008). Human capital formation and foreign direct: Investment in developing countries. OECD Journal: General Papers, 2008(1), 1-40.

Mottaleb, K.A. (2007). Determinants of foreign direct investment and its impact on economic growth in developing countries. MPRA paper, 9457.

Nunnenkamp, P. (2002). Foreign direct investment in developing countries: what economists don't know and what policymakers should not do. Vol. 380. Kiel: Institut für Weltwirtschaft.

Peters, P. (2002). Legal systems as a determinant of FDI: Lessons from Sri Lanka. Netherlands International Law Review, 49(2), 285-287.

Pierpont, B. (2007). Democracy, property rights and FDI in developing countries: A regional analysis. Macalester College, Working Paper.

Porta, R., Lopez-De-Silanes, F., Shleifer, A. \& Vishny, R. (1997). Legal determinants of external finance. The Journal of Finance, 52(3), 1131-1150.

Rodrik, D. (Ed.). (2012). In search of prosperity. Princeton University Press.

Schneider, F. \& Frey, B. (1985). Economic and political determinants of foreign direct investment. World Development, 13(2), 161-175.

Seim, L.T. (2010). FDI and openness: Differences in response across countries line, Chr. Michelsen Institute, Working Paper. 
Shah, M.H., (2009). FDI induced growth in developing countries: does human capital matter? PhD Conference. $5^{\text {th }} \& 11^{\text {th }}$ March, 2009. Economics Department, University of Leicester, Leicester, UK.

Shah, M.H., (2010). Bilateral linkages with OECD and FDI inflows in leading developing countries. The Fifth International Conference on Interdisciplinary Social Sciences. 2-5 August, 2010. University of Cambridge, Cambridge, UK.

Shah, M.H., (2011a). Bilateral linkages with OECD and FDI inflows in leading developing countries. International Journal of Interdisciplinary Social Sciences, 5(7), 255-270.

Shah, M.H. (2011b). Essays on foreign direct investment in developing countries (Doctoral dissertation, University of Leicester).

Shah, M.H., (2011c). The effect of associations with OECD economies on FDI inflows in leading/emerging developing countries. $4^{\text {th }}$ Italian Doctoral Workshop in Economics and Policy Analysis. 7-8 July, 2011. University of Torino and Collegio Carlo Alberto, Via Real Collegio 30, 10024 Moncalieri, Torino, Italy.

Shah, M.H., (2011d). Networking with OECD economies, enhancing inward FDI in emerging developing countries. $7^{\text {th }}$ UK Social Networks Conference. 7-9 July, 2011. University of Greenwich, Greenwich Campus, Old Royal Naval College, London, UK.

Shah, M.H., (2011e). World Trade Organisation and inward foreign direct investment in developing countries: is it TRIMS, TRIPS or Liberalisation? $6^{\text {th }}$ International Conference on Interdisciplinary Social Sciences. 11-13 July, 2011. University of New Orleans, 2045 Lakeshore Drive, CERM 245, New Orleans, LA 70122, USA.

Shah, M.H., (2011f). The significance of infrastructure for inward FDI in developing countries. International Conference on Applied Business \& Economics, ICABE, 2011. $29^{\text {th }}$ September to $1^{\text {st }}$ October, 2011. University of Applied Sciences, Metropolitan Hotel, 385 Syngrou Ave, 17564, Athens, Greece.

Shah, M.H., (2012a). The importance of adherence to Intellectual Property Rights (IPRs) treaties/conventions for FDI inflows in emerging economies: evidence from OECD outward FDI. International Network for Economic Research, 14 ${ }^{\text {th }}$ INFER Annual Conference. 10-13 May, 2012. Faculty of Economics, University of Coimbra, Portugal.

Shah, M.H., (2012b). The significance of infrastructure for FDI inflow in developing countries. International Network for Economic Research, 14 $4^{\text {th }}$ INFER Annual Conference. 10-13 May, 2012. Faculty of Economics, University of Coimbra, Portugal.

Shah, M.H., (2012c). The effect of macroeconomic stability on inward FDI in developing countries. $7^{\text {th }}$ International Conference on Interdisciplinary Social Sciences. 25-28 June, 2012. Universidad Abat Oliba CEU, Bellesguard 30-08022, Barcelona, Spain.

Shah, M.H., (2012d). The significance of infrastructure for FDI inflow in developing countries. Challenges for Analysis of the Business and the EconomyIScientific Conference. 13-16 September, 2012. University 
of Applied Sciences, Bahnhofstrasse, 15745 Wildau, Berlin, Germany.

Shah, M.H., (2013a). The importance of adherence to Intellectual Property Rights (IPRs) treaties/conventions for FDI inflows in emerging economies: evidence from OECD outward FDI. European Economics and Finance Society, EEFS2013, 12 ${ }^{\text {th }}$ Annual EEFS Conference. 20-23 June, 2013. Westin Grand, Berlin, Germany.

Shah, M.H., (2013b). The effect of macroeconomic stability on inward FDI in developing countries. European Economics and Finance Society, EEFS2013, 12 $2^{\text {th }}$ Annual EEFS Conference. 20-23 June, 2013. Westin Grand, Berlin, Germany.

Shah, M.H., (2014a). The role of human capital in the host economy on inward FDI in developing countries. West East Institute, European Academic Conference Budapest, WEI 2014, 22-25 June, 2014. Mercure Budapest Korona, Hungary. Organized by West East Institute, 19382 West Chester, PA, USA.

Shah, M.H., (2014b). The significance of infrastructure for FDI inflow in developing countries. Journal of Life Economics, 2, 1-16.

Shah, M.H., (2015). Impact of trade liberalization on FDI inflows in emerging countries. International Social Sciences and Education Research Conference ICBTS2015, 9-13 June, 2015 at Harvard University, Boston, Massachusetts, USA.

Shah, M.H., \& Faiz, M. (2015). Terrorism and foreign direct investment: An empirical analysis of SAARC countries. City University Research Journal. 5(2), 219-233.

Shah, M.H., \& Samdani, S. (2015). Impact of trade liberalization on FDI inflows to D-8 countries. Global Management Journal for Academic $\mathcal{E}$ Corporate Studies (GMJACS), 5(1), 30-37.

Smarzynska, B.K. (2002). The composition of foreign direct investment and protection of intellectual property rights: evidence from transition economies (No. 2786). The World Bank.

Soumaré, I., \& Tchana, F.T. (2015). Causality between FDI and financial market development: Evidence from emerging markets. The World Bank Economic Review, 29(1), 205-216.

Subasat, T., \& Bellos, S. (2013). Governance and foreign direct investment in Latin America: A panel gravity model approach. Latin American Journal of Economics, 50(1), 107-131.

UNCTAD. (2002). Transnational Corporations and Export Competitiveness. World Investment Report 2002. United Nations Conference on Trade and Development. New York and Geneva.

UNCTAD, G.V.C. (2013). Investment and Trade for Development. World Investment Report 2013. United Nations Conference on Trade and Development. New York and Geneva.

United Nations Development Programme. (1997). Untitled. Governance for Sustainable Human Development. UNDP, New York.

Voyer, P. \& Beamish, P. (2004). The effect of corruption on Japanese foreign direct investment. Journal of Business Ethics, 50(3), 211-224. 
Yu, J., \& Walsh, M.J.P. (2010). Determinants of foreign direct investment: A sectoral and institutional approach (No. 10-187). International Monetary Fund.

Wei, S.J., \& Shleifer, A. (2000). Local corruption and global capital flows. Brookings Papers on Economic Activity, 31(2), 303-354.

Wheeler, D. \& Mody, A. (1992). International investment location decisions: the case of U.S. Firms. Journal of International Economics. 33(1-2), 57-76.

White III, G.O., Chizema, A., Canabal, A., \& Perry, M.J. (2015). Legal system uncertainty and FDI attraction in Southeast Asia. International Journal of Emerging Markets, 10(3), 572-597.

World Bank. (1992). Governance and development. Washington, D.C: The World Bank.

World Bank. (2005). World Development Report. A Better Investment Climate for Everyone. Washington. D.C: The World Bank. 